Original Research Paper

\title{
Penyuluhan Tentang Usaha Perbaikan Gizi Keluarga (UPGK) Melalui Pemanfaatan Pekarangan dimasa Pandemi Covid 19
}

\author{
Kusmiyati $^{1 *}$, Dewa Ayu Citra Rasmi ${ }^{1}$, Khairuddin ${ }^{1}$, Prapti Sedijani1, Baiq Sri Handayani ${ }^{1}$ \\ ${ }^{1}$ Program Studi Pendidikan Biologi FKIP Universitas Mataram, Mataram, Indonesia
}

https://doi.org/10.29303/jpmpi.v3i2.967

Sitasi: Kusmiyati., Rasmi, D. A. C., Khairuddin., Sedijani, P \& Handayani, B. S. (2021). Penyuluhan Tentang Usaha Perbaikan Gizi Keluarga (UPGK) Melalui Pemanfaatan Pekarangan dimasa Pandemi Covid 19. Jurnal Pengabdian Magister Pendidikan IPA, 4(3)

\author{
Article history \\ Received: 30 Agustus 2021 \\ Revised: 17 September 2021 \\ Accepted: 18 September 2021 \\ *Corresponding Author: \\ Kusmiyati, Program Studi \\ Pendidikan Biologi FKIP \\ Universitas Mataram, \\ Mataram, Indonesia. Email: \\ kusmiyati.fkip@unram.ac.id
}

\section{Pendahuluan}

Pandemi Covid 19 sudah berlangsung dari bulan Maret 2020 hingga sekarang, sejak itu semua aktivitas perkantoran, sekolah dilakukan dari rumah. Kegiatan perkuliahan juga dilakukan dari rumah, sehingga sebagian besar mahasiswa yang

\begin{abstract}
Pandemi Covid 19 sudah berlangsung dari bulan Maret 2020, sejak itu berbagai aktivitas yang dilakukan masyarakat biasanya terkait dengan menjaga agar imunitas tubuh tetap terjaga. Menjaga imunitas tubuh tidak terlepas dari pemenuhan gizi sehari-hari. Usaha Perbaikan Gizi Keluarga (UPGK) merupakan sebuah usaha untuk melakukan kegiatan terpadu, bertujuan untuk menanggulangi kekurangan gizi atau untuk memperbaiki gizi masyarakat. Tujuan dari pengabdian ini adalah mengajak mahasiswa agar mau memanfaatkan pekarangan untuk perbaikan gizi keluarga. Kegiatan pengabdian ini dilaksanakan dengan beberapa tahap, yaitu tahap persiapan, tahap observasi, tahap pelaksanaan kegiatan dan tahap pelaporan. Metode yang digunakan meliputi: (a) Metode ceramah, digunakan untuk menyampaikan materi usaha perbaikan gizi keluarga melalui pemanfaatan pekarangan di masa pandemi covid 19. (b). Metode tanya jawab, digunakan untuk memberikan umpan balik pada peserta sekaligus untuk mendapatkan tanggapan peserta tentang materi yang telah disampaikan selama kegiatan. Selain itu, untuk evaluasi kegiatan pengabdian ini dilakukan pretes dan postes. Hasil pengabdian menunjukkan bahwa antusias mahasiswa pada saat pelaksanaan kegiatan sangat tinggi, terlihat mahasiswa mengikuti dari awal hingga akhir, pada waktu dilakukan pretes dan postes, mahasiswa mengirim kembali jawaban pertanyaan melalui google form. Selanjutnya ketika penyampaian materi, mahasiswa juga dapat diajak interaksi, dengan mengajukan pertanyaan dari materi yang disampaikan. Hasil penghitungan gain ternormalisasi sebesar 0,53 Kesimpulan dari kegiatan pengabdian ini adalah: a). Pengetahuan mahasiswa tentang UPGK dan pemanfaatan pekarangan meningkat, dalam kategori sedang; b). Pemanfaatan pekarangan perlu ditata dengan mengedepankan keberagaman spesies untuk kebutuhan dapur, sehingga dapat memenuhi kebutuhan gizi dan memperbaiki gizi keluarga di masa pandemi covid 19.
\end{abstract}

Keywords: UPGK, pekarangan, covid-19

biasa tinggal di rumah kost, tinggal di rumah masing-masing bersama orang tuanya. Masyarakat menjadi kreatif memanfaatkan waktu untuk menghilangkan kejenuhan di rumah. Salah satu kegiatan yang sedang marak akhir-akhir ini adalah menanam tanaman hias di halaman rumah, atau 
mencoba resep-resep yang selama ini hanya dinikmati dari warung makanan di luar rumah.

Berbagai aktivitas yang dilakukan masyarakat biasanya terkait dengan menjaga agar imunitas tubuh tetap terjaga dalam menghadapi pandemi covid 19. Menjaga imunitas tubuh tidak terlepas dari pemenuhan gizi sehari-hari. Hal ini sesuai dengan tujuan nasional penyelenggaraan kesehatan, yang bertujuan tercapainya kemampuan untuk hidup sehat bagi setiap penduduk agar dapat mewujudkan derajat kesehatan yang optimal sebagai salah satu unsur kesejahteraan. Untuk mencapai program tersebut dilaksanakan kegiatan yang disebut Usaha Perbaikan Gizi Keluarga (UPGK), yang menurut Moehji (1987) merupakan kegiatan masyarakat Indonesia yang bersifat lintas sektoral yang dilaksanakan oleh Departemen terkait yaitu Kesehatan, Pertanian, BKKBN, Agama, Tim Penggerak PKK dan lain-lain.

Usaha Perbaikan Gizi Keluarga sangat penting dalam pembangunan kualitas sumber daya manusia, sebab keadaan gizi mempunyai kaitan erat dengan tingginya angka penyakit dan angka kematian. Selain itu, meningkatnya keadaan gizi penduduk merupakan sumbangan yang besar dalam pencerdasan bangsa, dan_membaiknya status gizi dan kesehatan akan memperbaiki kualitas sumber daya manusia dan sekaligus akan meningkatkan produktivitas kerja. UPGK merupakan sebuah usaha untuk melakukan kegiatan terpadu, bertujuan untuk menanggulangi kekurangan gizi atau untuk memperbaiki gizi masyarakat. Adapun kegiatan pokok dalam UPGK adalah: (a) penyuluhan gizi masyarakat; (b) Pelayanan gizi di posyandu;(c) Pemanfaatan pekarangan untuk meningkatkan gizi keluarga.

Program studi Pendidikan Biologi FKIP Unram, menyiapkan mahasiswanya untuk menjadi guru Sekolah Menengah Atas. Di program studi ini matakuliah Ilmu Gizi merupakan matakuliah pilihan, dan tidak semua angkatan memperoleh matakuliah tersebut, baru berlaku pada angkatan tahun 2019 atau yang sekarang semester 4. Materi yang di bahas dalam matakuliah Ilmu Gizi, salah satunya adalah Usaha perbaikan gizi keluarga. Pengetahuan tentang gizi mudah di dapat dari berbagai media, apalagi di jaman seperti sekarang segala informasi mudah di akses lewat internet, namun demikian belum tentu semua orang membuka materi-materi gizi terutama tentang usaha perbaikan gizi keluarga. Selain itu dalam masa pandemi sekarang, masyarakat banyak yang memanfaatkan halaman rumah dengan menanami tanaman hias. Kondisi ini menguntungkan sebab tim pengabdian bisa memaksimalkan pemahaman mereka tentang usaha perbaikan gizi keluarga melalui pemanfaatan pekarangan. Pemanfaatan pekarangan ini tentunya dikhususkan terutama dalam menghadapi pandemi covid 19, karena dalam masa ini masyarakat harus meningkatkan imunitas tubuhnya.

\section{Metode}

Kegiatan pengabdian ini berlangsung dalam tahapan-tahapan, meliputi:

a. Tahap persiapan, pada tahap ini diadakan persiapan tentang segala sesuatu yang dapat menunjang kegiatan pengabdian ini terlaksana dengan baik meliputi: (a) Merencanakan pembagian tugas anggota tim penyuluhan agar semaksimal mungkin dapat memberikan pengetahuan dan pemahaman yang memadai bagi mahasiswa/ peserta; (b) Mencari referensi untuk menyusun materi yang terkait dengan usaha perbaikan gizi keluarga melalui pemanfaatan pekarangan; (c) Menyusun instrumen untuk pretes dan postes; (d ) Menyusun acara untuk pelaksanaan kegiatan pengabdian; (e) Menyusun daftar hadir peserta.

b. Tahap observasi, pada tahap ini diadakan konsultasi dengan pihak sasaran tentang faktorfaktor yang mendukung dan menghambat pelaksanaan kegiatan penyuluhan, sehingga dapat dicarikan alternatif yang terbaik dalam pelaksanaannya. Kegiatan pengabdian ini bertepatan dengan kondisi pandemi covid 19, sehingga semua kegiatan dilaksanakan secara online. Keadaan ini membuat situasi dan kondisi yang harus benar-benar disesuaikan dengan situasi mahasiswa, melalui WhatsApp (WA) grop kelas, tim pengabdian mencari waktu mahasiswa yang benar-benar kosong, tidak ada pertemuan dengan dosen lain.

c. Tahap pelaksanaan kegiatan.

Pada tahap ini disampaikan materi tentang usaha perbaikan gizi keluarga melalui pemanfaatan pekarangan. Waktu pelaksanaan disesuaikan dengan kesepakatan antara anggota tim pengabdian dengan pihak mahasiswa Pendidikan Biologi semester 7 tahun ajaran 2021/2022. Akhirnya disepakati bahwa 
pengabdian dilaksanakan pada hari Senin tanggal 16 Agustus 2021, pukul 14.00 WITAselesai. Semua kegiatan dilaksanakan secara online melalui media WA grup, google meet dan google form.

WA grup digunakan untuk komunikasi dengan mahasiswa (peserta), dalam menentukan waktu pelaksanaan dan mengisi daftar hadir. Google meet digunakan untuk: (a) menyampaikan materi tentang UPGK dan pemanfaatan pekarangan; (b) tanya jawab tentang materi yang telah disampaikan, untuk memberikan umpan balik pada peserta sekaligus untuk mendapatkan tanggapan peserta selama kegiatan.

Google form digunakan untuk komunikasi dengan mahasiswa dalam melakukan (a) pretes untuk mengetahui pengetahuan awal mahasiswa tentang UPGK dan pemanfaatan pekarangan, dengan menjawab pertanyaan dan mengirim kembali jawaban lewat media yang sama; (b) melakukan postes untuk mengetahui pengetahuan mahasiswa setelah diberikan materi tentang UPGK dan pemanfaatan pekarangan, dengan menjawab pertanyaan dan mengirim kembali jawaban lewat media yang sama.

Kejujuran mahasiswa selama kegiatan juga dilihat, mahasiswa diingatkan untuk tidak mengirimkan jawaban pretes maupun postes, lebih dari satu kali. Apabila ada yang mengirimkan lebih dari satu kali, maka yang akan diambil sebagai jawabannya adalah yang terkirim pertama kali.

d. Tahap penyusunan laporan, pada tahap ini dilakukan penyusunan laporan kegiatan pengabdian sesuai dengan uraian materi yang disampaikan pada saat pelaksanaan pengabdian. Hasil pretes dan postes dari masing-masing mahasiswa dihitung dan di analisis untuk melihat peningkatan pengetahuan menggunakan rumus gain ternormalisasi (Hake dalam Fidiantara 2019). Gain ternormalisasi kemudian dibuat dalam 3 kategori yaitu: rendah, sedang dan tinggi.

Kegiatan pengabdian ini dilaksanakan dengan metode sebagai berikut:

a. Metode ceramah, digunakan untuk menyampaikan pengetahuan tentang UPGK melalui pemanfaatan pekarangan

Metode tanya jawab, digunakan untuk memberikan umpan balik pada peserta sekaligus untuk mendapatkan tanggapan peserta tentang materi yang telah disampaikan selama kegiatan. Selain itu, untuk evaluasi kegiatan pengabdian ini dilakukan tes sebelum dan sesudah pelaksanaan yang berkaitan dengan pemahaman peserta tentang UPGK melalui pemanfaatan pekarangan, menggunakan instrumen tes.

\section{Hasil dan Pembahasan}

Kegiatan pengabdian pada masyarakat ini dapat berjalan lancar, berkat dukungan dari pihak mahasiswa, meskipun komunikasi dilakukan melalui WhatsApp (WA) grup. Penentuan waktu pelaksanaan pengabdian disesuaikan dengan jadwal di kampus, karena bertepatan dengan pelaksanaan perkuliahan semester ganjil 2021/2022. Akhirnya disepakati pengabdian ini dilaksanakan pada hari Senin tanggal 16 Agustus 2021. Kegiatan dilaksanakan dengan surat tugas dari fakultas. Peserta yang menjadi sasaran pengabdian ini adalah mahasiswa Pendidikan Biologi FKIP Unram semester VII, sebanyak 23 mahasiswa. Peserta yang hadir mengikuti kegiatan dari awal hingga akhir.

Antusias peserta pada saat pelaksanaan kegiatan sangat tinggi, terlihat pada waktu pretes dan postes semua peserta mengerjakan dan mengirim kembali jawaban pertanyaan melalui google form. Selanjutnya ketika penyampaian materi, peserta juga dapat diajak interaksi, dengan mengajukan pertanyaan dari materi yang telah disampaikan. Rata-rata hasil tes yang dilakukan sebelum penyampaian materi (pretes) sebesar 68 dan rata-rata hasil tes setelah diberikan materi (postes) sebesar 80 . Hasil penghitungan gain ternormalisasi sebesar 0,53. Hal ini berarti bahwa pengetahuan tentang UPGK dan pemanfatan pekarangan mahasiswa meningkat dengan kategori sedang.

Pada kegiatan pengabdian ini, tidak dilakukan praktek pemanfaatan pekarangan, tim pengabdian hanya bisa berpesan atau mengajak mahasiswa, bahwa sebagai mahasiswa Pendidikan Biologi sudah seharusnya menjadi contoh di lingkungannya dalam memanfaatkan pekarangan. Sesempit 
apapun pekarangan rumahnya, sebisa mungkin berusaha menanam tanaman pekarangan untuk memenuhi kebutuhan dapur, selain dapat menikmati hasilnya, kita dapat selalu bersedekah untuk lingkungan yaitu sedekah oksigen. Mahasiswa Pendidikan Biologi semester 7 sudah mendapatkan materi lingkungan yang sangat banyak, sehingga kegiatan pengabdian ini dapat digunakan sebagai tambahan informasi bagaimana menerapkan materi lingkungan dalam memanfaatkan pekarangan. Pemanfaatan pekarangan juga diupayakan untuk dapat memenuhi kebutuhan protein, seperti memelihara ayam atau memelihara ikan di ember.

Sasaran pengabdian ini adalah mahasiswa semester 7 yang tidak mendapatkan materi Ilmu Gizi, walaupun materi gizi dapat diperoleh dari mana saja, namun dengan pelaksanaan pengabdian ini mahasiswa diajak untuk memperbaiki gizi keluarga melalui pemanfaatan pekarangan, untuk memenuhi kebutuhan dapur. Pemanfaatan pekarangan di masa pandemi covid 19, dimana mahasiswa mengerjakan segala tugas perkuliahan dari rumah, sehingga masih banyak waktu luang di sela-sel tugasnya, untuk berkebun atau menanam segala macam sayuran dan buahbuahan yang beranekaragam. Mahasiswa diajak seluas-luasnya untuk mengembangkan materi lingkungan, khususnya yang berhubungan dengan tanaman. Pengetahuan lingkungan yang dapat diterapkan dalam memanfaatkan pekarangan antara lain tentang keanekaragaman hayati, sehingga lingkungan rumahnya penuh dengan beranekaragam tanaman pangan yang dapat memperbaiki gizi keluarga.

Hasil penghitungan gain ternormalisasi diperoleh sebesar 0,53 dan hasil ini menunjukkan bahwa pengetahuan mahasiswa tentang UPGK melalui pemanfaatan pekarangan meningkat, dalam kategori sedang. Peningkatan pengetahuan ini dapat dipahami, dengan adanya penyampaian materi UPGK dan pemanfaatan pekarangan yang belum di dapatkan sebelumnya oleh mahasiswa, menambah pengalaman dan pengetahuan bagi mahasiswa. Materi disampaikan lewat google meet, dengan bantuan powerpoint, dengan demikian mahasiswa lebih mudah menangkap maksud dan memahami materi yang disampaikan. Seperti pendapat Djamarah dan Zain (2010), alat bantu pengajaran mempunyai fungsi untuk: a). meningkatkan persepsi; b). meningkatkan pengertian; c). meningkatkan transfer (pengalihan) belajar; d). memberikan penguatan atau pengetahuan hasil yang dicapai dan e). meningkatkan retensi (ingatan).

Pengabdian ini membekali mahasiswa tentang usaha perbaikan gizi keluarga (UPGK) melalui pemanfaatan pekarangan. Menumbuhkan kesadaran mahasiswa agar mau dan mampu memanfaatkan lahan pekarangan menjadi sumber pangan keluarga. UPGK merupakan kegiatan masyarakat yang berintikan penyuluhan gizi, melalui peningkatan peran serta masyarakat dan didukung kegiatan lintas sektoral. Kata lintas sektoral ini antara lain melibatkan instansi BKKBN, kesehatan, bangdes, agama, pertanian dan sebagainya. Kegiatan UPGK Kementrian Pertanian menurut Sajogja (2004) meliputi intensifikasi pekarangan berupa proyek aneka ternak dan aneka ikan merupakan pelaksanaa kegiatan yang dilaksanakan oleh departemen pertanian. Kegiatan lain yang dilaksanakan adalah kegiatan demonstrasi pengolahan bahan makanan hasil pekarangan yang bertujuan untuk meningkatkan pengetahuan, keterampilan, dan sikap positif masyarakat dalam upaya peningkatan gizi keluarga.

Kegiatan pokok dalam UPGK (Depkes, 2000) dibagi menjadi 3 yaitu UPGK dasar, UPGK lengkap dan UPGK intensif. Kegiatan UPGK tersebut meliputi penyuluhan gizi masyarakat, pelayanan gizi di Posyandu dan pemanfaatan pekarangan untuk meningkatkan gizi keluarga. Depkes RI (2001) menambahkan pada hakikatnya UPGK merupakan suatu tehnologi pada masyarakat. Tehnologi dimaskud adalah kegiatan UPGK 
yang antara lain berupa penyuluhan gizi terarah dan pemanfaatan pekarangan.

Mahasiswa merupakan bagian dari masyarakat yang juga harus menjalankan fungsi kemasyarakatan, sehingga mahasiswa juga merupakan sasaran dari kegiatan UPGK. Seperti pendapat Kodyat (1993), semua anggota masyarakat ikut serta dalam kegiatan UPGK, meluas ke semua dukuh atau banjar, RT, RW, kampung dan dusun. UPGK dilakukan oleh, dari dan untuk masyarakat. Tujuan umum dari UPGK adalah meningkatkan dan membina keadaan gizi seluruh anggota masyarakat. Melihat tujuan dan sasaran UPGK ini, maka sudah seharusnya mahasiswa bisa memberi contoh dilingkungannya, agar tercapai tujuan umum UPGK tersebut.

Perilaku yang mendukung kegiatan perbaikan gizi keluarga, antara lain setiap pekarangan dimanfaatkan untuk meningkatkan gizi keluarga. Pekarangan adalah tempat atau lahan di sekitar halaman rumah, bisa luas atau sempit. Kementerian Pertanian menginisiasi optimalisasi pemanfaatan pekarangan melalui konsep Rumah Pangan Lestari (RPL). Syawal (2015) menyebutkan RPL merupakan rumah penduduk yang dimanfaatkan pekarangannya untuk menyediakan pangan rumah tangga yang berkualitas. Dengan kata lain RPL adalah rumah yang memanfaatkan pekarangannya sebagai kebun gizi dalam menyediakan pangan yang berkualitas dalam rangka mencukupi kebutuhan gizi anggota keluarganya

Pekarangan memiliki potensi untuk dikembangkan sebagai penghasil pangan, dalam memperbaiki gizi keluarga sekaligus meningkatkan pendapatan keluarga. Manfaatnya sangat besar, terutama bagi masyarakat golongan ekonomi lemah. Apabila lahan pekarangan sempit, dapat dimanfaatkan untuk tanaman pangan bagi keperluan keluarga, khususnya sayur-sayuran, yang bisa ditanam di pot atau barang bekas seperti plastik bekas minyak, kaleng bekas cat dan sebagainya. Kebutuhan untuk protein dapat diperoleh dengan memelihara ikan di ember.
Apabila lahan cukup luas, bisa ditanami bermacam-macam buah-buahan, bahkan memelihara ternak kecil dan ikan, yang diperlukan keluarga sebagai sumber pangan dan gizi, dengan demikian pekarangan dimanfaatkan sebagai kebun gizi.

Kebun gizi harus ditata sedemikian rupa sehingga menarik pemandangan dengan mengedepankan keanekaragaman tanaman untuk kebutuhan dapur seperti tanaman sayuran, buah, serta tanaman obat/bumbu atau empon-empon. Bunga-bunga dapat ditanam di pingiran sayuran. Agar pemandangan sedap, dapat pula pot-pot yang ditaruh di depan rumah, ditanami tanaman yang berguna tetapi menarik pamandangan, misal cabe rawit, cabe besar, paprika, tomat, terong dan sebagainya. Buah yang berwarna warni menambah pemandangan, pikiran menjadi tenang, sehingga imunitas tubuh bisa terjaga,

Optimalisasi pekarangan dalam peningkatan gizi sebenarnya meliputi aspek yang kompleks, tidak hanya penanaman sayur atau buah saja, melainkan harus memenuhi semua aspek meliputi sumber energi misalnya jagung, umbi-umbian. Sumber protein nabati seperti sayur-sayuran, dan sumber protein hewani yakni dengan memelihara ternak atau ikan di pekarangan rumah. Dengan adanya pemanfaatan pekarangan untuk menanam beranekaragam tanaman pangan dan memelihara ternak kecil, sebuah keluarga selain dapat menyediakan bahan makanan yang beraneka ragam, menambah penghasilan keluarga, juga dapat memenuhi kebutuhan gizi mereka sendiri untuk kesehariannya dan mencapai ketahanan pangan di masa pandemi covid 19.

Makanan yang dikonsumsi keluarga harus memiliki kualitas dan kuantitas yang baik, mengandung zat gizi yang lengkap yaitu karbohidrat, protein, lemak, vitamin, mineral dan air. Masing-masing zat gizi memiliki perannya masing-masing, sehingga keenam zat gizi tersebut dikelompokkan sebagai penghasil tenaga, sebagai pembangun tubuh dan pengatur fungsi tubuh. 
Keenam zat gizi tersebut akan terpenuhi apabila keluarga memanfatkan pekarangan dengan baik, ditata dan dikelola dengan baik. Almatsier (2016) menambahkan selain keenam zat gizi tersebut, tubuh juga memerlukan serat, serat merupakan bagian dari karbohidrat, yaitu karbohidrat kompleks. Serat tidak dapat dicerna oleh pencernaan tubuh, namun memiliki manfaat untuk melancarkan saluran pencernaan.

Berbagai jenis tanaman pangan yang biasa di tanam di pekarangan antara lain jenis tanaman untuk tanaman penghasil umbi sebagai sumber karbohidrat, misalnya singkong, ubi, bengkoang, garut, ganyong, gadung, tales, gembili dan lain-lain. Jenis tanaman sayuran antara lain: bayam, kangkung, belimbing wuluh, kenikir, gambas, labu, tomat, kemangi, kecipir, katuk, kelor, turi, kacang panjang dan sebagainya. Jenis tanaman buah antara lain: nanas, sirsak, apokat, kelengkeng, anggur, sirkaya, manggis, jambu biji, jambu air, nangka, pepaya, jeruk, buah naga, matoa, pisang, mangga, belimbing dan sebagainya. Jenis tanaman rempah/bumbu antara lain: lengkuas, sere, jeruk purut, sere, suji, pandan, salam, kunyit,kencur, asem dan sebagainya. Jenis tanaman obat antara lain: lidah buaya, binahong, kunyit, kencur, sirih, mengkudu, jahe, kencur, camcao dan sebagainya. Jenis tanaman empon-empon sebetulnya merupakan jenis tanaman rempah/ obat antara lain: kunyit, jahe,kencur, temu hitam, temu lawak, sereh dan sebagainya

\section{Kesimpulan}

Kesimpulan dari kegiatan ini adalah: (1). Pengetahuan mahasiswa tentang UPGK dan pemanfaatan pekarangan meningkat, dalam kategori sedang. (2). Pemanfaatan pekarangan perlu ditata dengan mengedepankan keberagaman spesies untuk kebutuhan dapur, sehingga dapat memenuhi kebutuhan gizi dan memperbaiki gizi keluarga di masa pandemi covid 19.

\section{Ucapan Terimakasih}

Tim pengabdian mengucapkan terimakasih kepada Universitas mataram dan LPPM UNRAM yang telah memfasilitasi kegiatan ini dan juga kepada semua pihak yang telah mendukung pelaksanaan kegiatan ini.

\section{Daftar Pustaka}

Almatsier S. 2016. Prinsip Dasar Ilmu Gizi. Jakarta: PT. Gramedia Pustaka Utama. Djamarah,S.B. dan Zain A. 2010.Strategi Belajar Mengajar. Jakarta: Rineka Cipta

Depkes RI, 2000. Makanan Pendamping Air Susu Ibu. Kementrian Kesehatan Republik Indonesia. Jakarta.

Depkes RI. 2001. Pedoman Umum Gizi Seimbang. Direktorat Bina Gizi Masyarakat. Jakarta.

Fidiantara, F. 2019, Pengaruh Penggunaan Bahan Ajar IPA Materi Sistem Ekskresi Berbasis Inkuiri Terhadap peningkatan Literasi Sains Siswa Kelas VII MTs Negeri I Mataram (Skripsi), Universitas Mataram, Mataram

Kodyat,1993,Program UPGK dalam Upaya meningkatkan kualitas sumberdaya manusia dan masyarakat Indonesia, IPB Bogor.

Moehji, 1987, Ilmu Gizi, Bhratara Karya Aksara, Jakarta

Sajogyo, 2004. Usaha Perbaikann Gizi Keluarga. Kementrian Kesehatan. Jakarta

Syawal. 2015. KRPL Kawasan Rumah Pangan Lestari Mendukung Percepatan Perbaikan Gizi. Kementrian Kesehatan RI Direktorat Jendral Kesehatan Masyarakat Direktorat Gizi masyarakat. 